\title{
Effect of application of excreta of livestock animals and methods of their decomposition on the growth parameters of tomato (Lycopersicum esculentum L.)
}

\author{
PARAS NATH, INDRA RAJ SINGH* AND ISIKELI TUITUBOU \\ College of Agriculture, Fisheries and Forestry, Fiji National University, KORONIVIA, FIJI \\ (Email : indrarajsingh@gmail.com)
}

\begin{abstract}
Field trial was conducted during 2013 - 2014 to assess the effects of application of different types of livestock animals excreta and methods of their decomposition on tomato (Lycopersicum esculentum L.) crop growth parameters like plant height and number of compound leaves at 30 days after transplanting and at harvest stage; number of fruits per plant; fruits weight and volume were recorded. The results of this study showed that the plant height and number of compound leaves at 30 days after transplanting and at harvest stageand fruit weight and fruit volume were maximum in case of poultry followed by goat and minimum in case of duck excreta. Methods of decomposition also exhibited a significant difference in growth parameters of tomato. The highest growth and yield were recorded in $\mathrm{T}_{3}$ (Animal excreta + Crop residues + Earthworm) followed by $\mathrm{T}_{2}($ Animal excreta + Earthworm) and least was obtained from $\mathrm{T}_{1}$ (Animal excreta).
\end{abstract}

Key Words : Tomato, Animal excreta, Vermicompost, Plant height, Fruit number, Leaves, Fruit weight

View Point Article : Nath, Paras, Singh, Indra Raj and Tuitubou, Isikeli (2017). Effect of application of excreta of livestock animals and methods of their decomposition on the growth parameters of tomato (Lycopersicum esculentum L.). Internat. J. agric. Sci., 13 (2) : 271-275, DOI:10.15740/HAS/IJAS/13.2/271-275.

Article History : Received : 20.02.2017; Revised : 16.04.2017; Accepted : 30.04.2017

* Author for correspondence: 